\title{
Animal-Assisted Therapy in Palliative Care
}

\section{Terapia Assistida com Animais nos Cuidados Paliativos}

\author{
Vanessa QUINTAL ${ }^{1}$, Paulo REIS-PINA $\square^{2,3}$ \\ Acta Med Port 2021 Oct;34(10):690-692 - https://doi.org/10.20344/amp.13164
}

\section{ABSTRACT}

There are still many cases where traditional medical care does not provide a realistic solution for patients with devastating diseases so other interventions should be adopted. We present a case report of a 76 year-old woman admitted to a Palliative Care unit due to stage IV colon adenocarcinoma, and we describe the contribution of a six-year-old Yorkshire terrier in her symptom management. Animal-assisted therapy can be of great use in palliative care, contributing to the patients' pain management, relief from suffering and improvement of quality of life.

Keywords: Animal-Assisted Therapy; Complementary Therapies; Holistic Health; Palliative Care

\section{RESUMO}

Existem casos em que os objetivos tradicionais dos cuidados médicos não apresentam soluções realistas para curar os doentes que enfrentam doenças devastadoras; devendo outros métodos ser aplicados. Os autores apresentam o caso clínico de uma mulher de 76 anos admitida numa unidade de Cuidados Paliativos devido a um adenocarcinoma do cólon estadio IV, e descrevem o papel que um Yorkshire terrier, de seis anos, teve no controlo sintomático desta doente. A terapia assistida por animais pode ser de grande utilidade quando usada com um objetivo terapêutico em cuidados paliativos, ajudando a reduzir a dor e o sofrimento dos doentes, aumentando a qualidade de vida. A terapêutica assistida por animais pode ser de grande utilidade nos cuidados paliativos, contribuindo para a gestão da dor dos doentes, alívio do sofrimento e melhoria da qualidade de vida.

Palavras-chave: Cuidados Paliativos; Saúde Holística; Terapia Assistida com Animais; Terapias Complementares

\section{INTRODUCTION}

The American Medical Association described palliative care as a "therapy focused on decreasing pain and suffering by providing symptom-relieving treatments, along with comfort and support for patients of all ages". ${ }^{1}$ In a time when medical treatment strategies are in profound and continuous development, there are still many cases where traditional medical care does not provide a realistic solution for patients with devastating health problems. For those cases alternative methods must be adopted. ${ }^{2}$

There has been a greater interest in the impact that the animal company can have on patients and their physical, emotional and spiritual well-being. ${ }^{3,4}$ Animal-assisted therapy (AAT) is a group of interventions involving the incorporation of trained animals in a healthcare setting to achieve a specific therapeutic outcome. ${ }^{1}$ Trained animals can be of great benefit in palliative care when used for therapeutic purposes in pain control, suffering management and better quality of life. ${ }^{1}$ These benefits have been observed particularly among the elderly. ${ }^{5}$ Although some studies have considered the physical and psychological benefits of AAT, the overall results are inconclusive. ${ }^{3,6}$ In conventional medicine, the use of animals is rare because the health system barely addresses the real needs of the patients and is often not centered on the healing process of a vulnerable human being.

The authors describe a clinical case which originality lies in the use of an animal at the service of the human person, with full respect for the patient's self-determination. This report reinforces the importance of the non-pharmacological approach in the holistic treatment of patients in palliative care.

\section{CLINICAL CASE}

76-year-old woman, former maid, recently active as a volunteer at the Parish Council and attending a senior university. She had been a widow since 2012, and her family support system included her daughter, son-in-law and granddaughter. She was diagnosed with stage IV colorectal cancer in 2012 with bone and liver metastasis. Due to cancer, she suffered pulmonary thromboembolism in 2016 and portal system thrombosis in 2017.

As the disease progressed, she had to be admitted in a Palliative Care unit for symptomatic control. On admission, her palliative performance scale was $50 \%{ }^{7}$ It was found that the patient's main companion since her husband's death and diagnosis, was a six year-old Yorkshire terrier named Cookie, a gift from her daughter, with whom the dog was currently staying. According to the unit's philosophy, the patient was informed that she could be visited by her pet, which made her visibly pleased. Considering the distance between the unit and the daughter's residence, the family and the pet could only visit the patient during the weekends.

\footnotetext{
1. Unidade de Cuidados de Saúde Personalizados Sete Rios. Agrupamento de Centros de Saúde de Lisboa Norte. Lisboa. Portugal.

2. Unidade de Cuidados Paliativos Bento Menni. Casa de Saúde da Idanha. Sintra. Portugal.

3. Centro de Medicina Paliativa. Faculdade de Medicina. Universidade de Lisboa. Lisboa. Portugal.

$\triangle$ Autor correspondente: Paulo Reis-Pina. paulopina@medicina.ulisboa.pt

Recebido: 19 de novembro de 2019 - Aceite: 01 abril de 2020 - First published: 15 de setembro de 2020 - Online issue published: 01 de outubro de 2021 Copyright $\odot$ Ordem dos Médicos 2021
} 
Healthcare providers noticed a change in the patterns of rescue therapy prescribed, both for pain and dyspnea, during the pet's visits. She only needed two rescue drugs or less, on average, these days. Similarly, the Edmonton Symptom Assessment System had, on average, lower scores in some symptoms, ${ }^{8}$ - namely pain, dyspnea, anxiety, depression, tiredness and drowsiness, - when daily weekday assessments were compared with weekend evaluations.

As mentioned by the patient, these moments, "although scarce, were revitalizing and make the environment more familiar".

\section{DISCUSSION}

The use of animals in the 'healing' process is rare and goes beyond the 'treatment' measurements of conventional medicine. The originality of this case-report lies in an animal being put at the service of the terminally ill person, and thus respecting the self-determination of the human being and her value system.

Studies about the relationship between positive impact of animals in human health and well-being started being documented in the $18^{\text {th }}$ century. ${ }^{9}$ In 2007 , Orlandi et al found that including therapy dog visits during chemotherapy reduced anxiety and depression. ${ }^{10}$ Later on, Moretti et al showed that pet therapy improved depressive symptoms in residents in a long-term care facility. ${ }^{5}$ Moreover, she established that self-perceived quality of life was also greatly improved. ${ }^{5}$ Engelman, surprisingly, noticed that staff stress levels appeared to decrease as a result of interactions with the therapy dog. ${ }^{1}$ In 2015, White et al suggested that AAT acts as a facilitator of the therapeutic alliance. ${ }^{3}$ AAT can significantly reduce pain, anxiety, depression and fatigue in cancer patients as revealed in several recent studies. ${ }^{2}$

Most healthcare institutions restrict the entry of animals due to hospital infection control standards. In this case report, the dog entered the patient's room through a window that gave access to a courtyard.

The beneficial effect of pet therapy has different possible explanations. ${ }^{5}$ Studies of the effect of AAT in patients show reduced heart and respiratory rates, decreased blood pressure and pupillary constriction and increased peripheral skin temperature. ${ }^{1}$ Other studies report reduction of loneliness, entertainment and better sleep. ${ }^{4}$ According to the affective-emotional mechanism hypothesis, a relaxing human-animal bond acts on adrenal and other corticosteroid hormones. ${ }^{5}$ Reports of reduced pain in patients are sustained by studies that detected decreased catecholamine and increased endorphin levels in humans receiving friendly dog visits. ${ }^{2}$ Thus, it appears that pet therapy may facilitate relaxation which, in turn, may reduce the affective and sensory components of some types of pain, resulting in a sort of 'hypnoalgesia'.'

In the description of this clinical case there are several limitations.

In this report, the pet was not trained for therapeutic purposes. However, given the relative scarcity of higher quality studies on the subject, the authors decided to do a review on 'pet or animal assisted therapy'. The Medical Subject Headings states that 'animal facilitated therapy' or 'pet facilitated therapy' is "the use of live animal as a means of therapy". ${ }^{11}$

Assessments were performed by several professionals and not at regular time intervals. It was not possible to control for all factors that could influence the clinical results showed in this report. It was not possible to have the family and the pet visit separately. However, it was possible to observe gains in symptomatic control when the family would bring the companion animal along as opposed to visiting without it.

Even though there is a strong tendency in the literature to assume that human-animal companion interactions are beneficial, there is a lack of unequivocal hard evidence. ${ }^{6}$ The main limitations of studies in this field still remain: poor research designs and difficulties in associating the use of animals with health outcomes. ${ }^{6}$ The role of AAT as a complementary therapy in palliative care is still being investigated. Therefore, larger clinical trials are needed in order to acknowledge their importance.

In the $21^{\text {st }}$ century, medicine needs not only to find new ways to 'diagnose and treat' diseases, but to ascertain new ways of 'caring' for sick human beings. ${ }^{12}$ The innovation of Medicine lives in the humanization of the medical act by putting the patient at the heart of the health system. Therefore, it seems appropriate to say that animals can potentially provide benefits to patients in palliative care. ${ }^{13}$

\section{AUTHORS CONTRIBUTION}

VQ, PRP: Contribution to the draft, critical review and final approval of the final version of the paper.

\section{PROTECTION OF HUMANS AND ANIMALS}

The authors declare that the procedures were followed according to the regulations established by the Clinical Research and Ethics Committee and to the Helsinki Declaration of the World Medical Association published in 2013

\section{DATA CONFIDENTIALITY}

The authors declare having followed the protocols in use at their working center regarding patients' data publication.

\section{INFORMED CONSENT}

Obtained.

\section{COMPETING INTERESTS}

The authors have declared that no competing interests exist.

\section{FUNDING SOURCES}

The authors received no financial support for the research, authorship and/or publication of this article. 
1. Engelman SR. Palliative care and use of animal-assisted therapy. Omega. 2013;67:63-7.

2. Petranek S, Pencek J, Dey M. The effect of pet therapy and artist interactions on quality of life in brain tumor patients: a cross-section of art and medicine in dialog. Behav Sci. 2018;8:piiE43.

3. White JH, Quinn M, Garland S, Dirkse D, Wiebe P, Hermann M, et al. Animal-assisted therapy and counseling support for women with breast cancer: an exploration of patient's perceptions. Integr Cancer Ther. 2015;14:460-7.

4. Chur-Hansen A, Zambrano SC, Crawford GB. Furry and feathered family members - a critical review of their role in palliative care. Am J Hosp Palliat Med. 2014;31:672-7.

5. Moretti F, De Ronchi D, Bernabei V, Marchetti L, Ferrari B, Forlani C, et al. Pet therapy in elderly patients with mental illness. Psychogeriatrics. 2011;11:125-9.

6. Chur-Hansen A, Stern C, Winefield H. Gaps in the evidence about companion animals and human health: some suggestions for progress. Int J Evid Based Healthc. 2010;8:140-6.

7. Anderson F, Downing GM, Hill J, Casorso L, Lerch N. Palliative performance scale (PPS): a new tool. J Palliat Care. 1996;12:5-11.

8. Bruera E, Kuehn N, Miller MJ, Selmser P, Macmillan K. The Edmonton Symptom Assessment System (ESAS): a simple method for the assessment of palliative care patients. J Palliat Care. 1991;7:6-9.

9. Fleishman SB, Homel P, Chen MR, Abolencia V, Gerber J, Nadesan $S$. Beneficial effects of animal-assisted visits on quality of life during multimodal radiation-chemotherapy regimens. J Community Support Oncol. 2015;13:22-6.

10. Orlandi M, Trangeled K, Mambrini A, Tagliani M, Ferrarini A, Zanetti L, et al. Pet therapy effects on oncological day hospital patients undergoing chemotherapy treatment. Anticancer Res. 2007;27:4301-3.

11. Medical Subject Headings 2020. U.S. National Library of Medicine [accessed 2020 Feb 22]. Available from: https://meshb.nlm.nih.gov/ record/ui?ui=D056447.

12. Lobo Antunes J. Ouvir com outros olhos. Ensaios. Lisboa: Gradiva; 2015.

13. Macdonald JM, Barrett D. Companion animals and well-being in palliative care nursing: a literature review. J Clin Nurs. 2016;25:300-10.
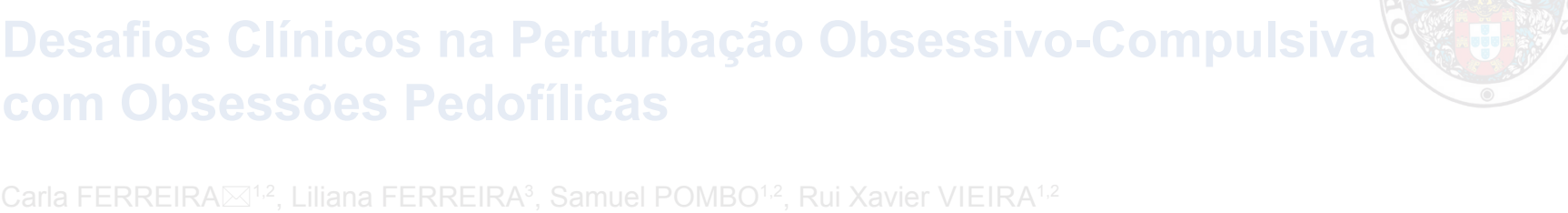

Acta Med Port 2021 Oct;34(10):692-695

ABSTRACT

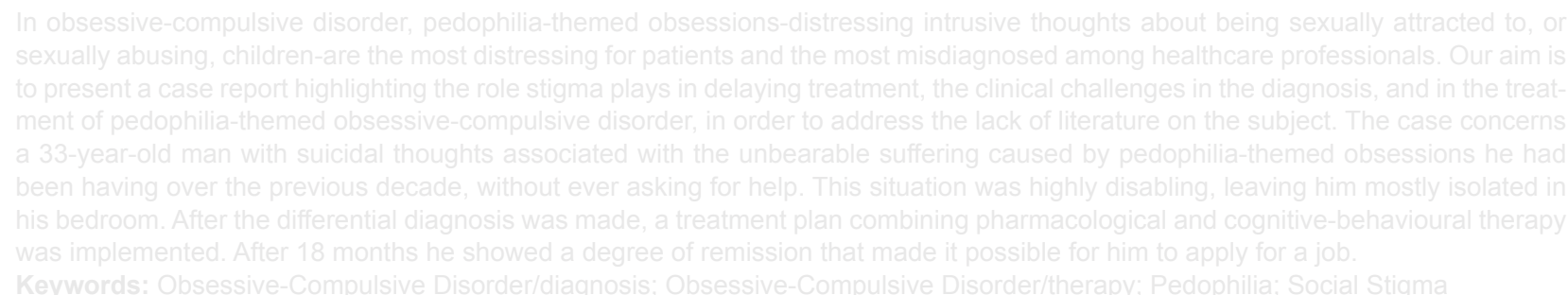

RESUMO

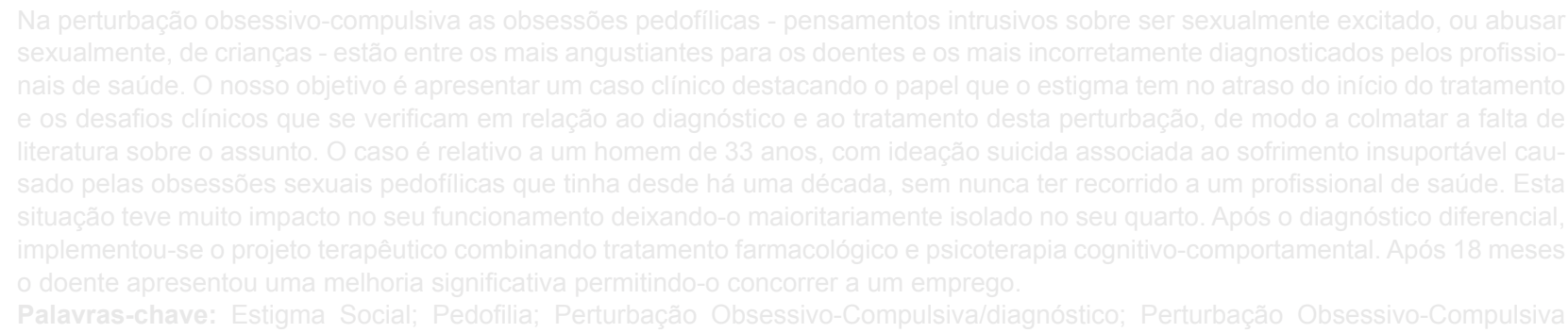

